\title{
Localization and Changes in NADPH- Diaphorase Reactivity and Nitric Oxide Synthase Immunoreactivity in Rat Pulp Following Tooth Preparation
}

\begin{abstract}
A.S. Law ${ }^{1,2}$, K.R. Baumgardner ${ }^{3,4}$, S.T. Meller ${ }^{2 *}$, and G.F. Gebhart ${ }^{2}$
Departments of 'Endodontics and ${ }^{2}$ Pharmacology, University of Iowa, Iowa City, Iowa, USA; ${ }^{3}$ Department of Cariology, Restorative Sciences, and Endodontics, School of Dentistry, University of Michigan, 1011 N. University St., Ann Arbor, Michigan 48109-1078, USA; ${ }^{*}$ current address OTCHCTD, The Procter \& Gamble Co., Health Care Research Center, 8700 Mason-Montgomery Rd, Mason, Ohio 45040-9462; "4to whom correspondence and reprint requests should be addressed
\end{abstract}

\begin{abstract}
Inflammatory changes in the dental pulp are accompanied by release of a wide variety of chemical mediators. Nitric oxide, an oxidative free radical produced by the enzyme nitric oxide synthase (NOS), has been implicated in multiple inflammatory processes, which makes it a suitable marker for changes which likely occur following tooth pulp insult. Since limited information on nitric oxide in the pulp is available, it is necessary first to examine relative distributions of NOS in uninflamed and inflamed rat pulp. We accomplished this by characterizing regions of nicotinamide adenine dinucleotide phosphate diaphorase (NADPH-d) activity and the distribution of both macrophage NOS (macNOS) and neuronal NOS (nNOS) immunoreactivity in normal and inflamed rat molar pulp at multiple time points. The results showed that: (1) deep cavity preparation on the mesial surface of the molar produced a time-dependent inflammation, with acute inflammation early progressing to chronic, granulomatous inflammation with necrosis later that spread preferentially down the mesial root; (2) control (non-prepared) teeth showed a relatively faint and homogeneous distribution of NADPH-d and macNOS reactivity but no discernible nNOS reactivity; (3) inflamed teeth displayed localized increased intensity of NADPH-d and macNOS reactivity surrounding the inflamed area of pulp, but no increased nNOS activity; (4) pulp vessels supplying the inflamed area showed increased NADPH-d reactivity, but no increased macNOS or nNOS reactivity; and (5) neither NADPH-d, macNOS, nor nNOS reactivity was observed in pulpal nerves. Therefore, nitric oxide may mediate the pulpal inflammatory response through its effects on the paralesional pulp tissue and surrounding endothelial/vascular structures.
\end{abstract}

Key words: pulpal inflammation, NADPH-diaphorase, nitric oxide synthase, nitric oxide, blood vessel.

Received March 4, 1998; Last Revision January 20, 1999;

Accepted January 28, 1999

\section{Introduction}

Inflammation can result from mechanical, chemical, or bacterial insult. Release of a wide variety of chemical mediators is involved in inflammatory changes in the pulp, including histamine (Pohto and Antila, 1970; DelBalso et al., 1976), prostaglandins (Hirafuji et al., 1980, 1982; Hirafuji and Ogura, 1987), and neuropeptides such as calcitonin gene-related peptide (CGRP) (Gazelius et al., 1987; Khayat et al., 1988; Grutzner et al., 1992) and substance P (Brodin et al., 1981; Wakisaka et al., 1984; Gazelius et al., 1987; Grutzner et al., 1992). In the pulp, inflammation can lead to alterations in: (1) blood flow (Okiji et al., 1989; Takahashi, 1990; Olgart et al., 1991); (2) immunocompetent cell function (Bergenholtz et al., 1977; Pulver et al., 1977; Hahn et al., 1989; Bergenholtz et al., 1991); and (3) neuronal activity (Ahlberg, 1978; Panopoulos et al., 1983; Närhi and Hirvonen, 1983; Madison et al., 1992). While several mediators have been shown to be involved in one or more of these processes, nitric oxide is involved in all three (Moncada et al., 1991).

Nitric oxide is a free radical gas that is produced by NO synthase (NOS) (Bredt et al., 1990, 1991). NOS uses molecular oxygen and arginine as substrates to produce $\mathrm{NO}$ and citrulline. Production of NO by NOS requires several co-factors, including nicotinamide adenine dinucleotide phosphate (NADPH), tetrahydrobiopterin, and flavins (flavin adenin dinucleotide and flavin mononucleotide). At least 3 isoforms of NOS have been cloned: an endothelial NOS (eNOS); a constitutive or neuronal NOS (nNOS); and an inducible or macrophage NOS (macNOS). Constitutive forms of NOS are activated by

Abbreviations used in this paper: NO, nitric oxide; NOS, nitric oxide synthase; NADPH-d, nicotinamide adenine dinucleotide phosphate diaphorase; macNOS, macrophage NOS; iNOS, inducible NOS; nNOS, neuronal NOS; eNOS endothelial NOS; H\&E, hematoxylin and eosin; CGRP, calcitonin gene-related peptide; MGLV, mean gray level value; NGS, normal goat serum; PB, phosphate buffer; PBS, phosphate-buffered saline; L-NAME, $\mathrm{N}^{\mathrm{G}}$. nitro-L-arginine methyl ester. 
agonists that increase calmodulin-NOS interaction via increased intracellular $\mathrm{Ca}^{2+}$. The inducible isoforms, such as macNOS, have been shown to be independent of increases in intracellular $\mathrm{Ca}^{2+}$ levels and are typically not expressed in noninflamed tissue. Rather, cytokines and other pro-inflammatory products have been shown to result in induction of inducible forms of NOS (Nussler and Billiar, 1993).

Since NADPH is a strict co-factor requirement for NO production, several investigators have used NADPH-diaphorase activity as a marker for NO synthase. The presence of NADPH-d activity has been used to localize NOS in trigeminal ganglion (Aimi et al., 1991), uninflamed tooth pulp, and tooth-supporting bone (Kerezoudis et al., 1993), but has not been investigated following tissue insult.

The enzymatic activity responsible for synthesis of NO in all systems studied to date is inhibited by the L-arginine analogs such as $\mathrm{N}^{\mathrm{G}}$-nitro-l-arginine methyl ester (L-NAME) (Marletta, 1989; Rees et al., 1990). These L-arginine analogs have shown protection from NO damage in several models of ischemia/re-perfusion injury and inflammation (Parks et al., 1982; Mulligan et al., 1991; Ashwal et al., 1994). Some physiologic data are available on the presence of the L-arginine/NO pathway in the dental pulp. For example, infusion of LNAME has been demonstrated significantly to reduce basal blood flow in the tooth pulp of the rat (Kerezoudis et al., 1993) and cat (Lohinai et al., 1995). NADPH-d activity has been reported to co-localize with NOS in peripheral neural tissues (Dawson et al., 1991; Ward et al., 1992; Grozdanovic et al., 1992) and non-neural tissues (Janssens et al., 1992; Lamas et al., 1992; Poeggel et al., 1992). To date, however, no data are available as to the localization and/or activity of NOS in inflamed pulp tissue.

The involvement of NO in multiple processes which occur during inflammation makes it an ideal marker for changes which likely occur following tooth pulp insult. Since NADPH-d activity has been localized in the uninflamed rat tooth pulp (Kerezoudis et al., 1993), and antibodies have been developed for some of the cloned subtypes of NOS, the purpose of this study was to examine and compare the distribution of NOS in the uninflamed and inflamed rat pulp by characterizing NADPH-d reactivity, and macNOS and $\mathrm{nNOS}$ immunoreactivity.

\section{Materials and methods}

\section{Animals}

Twenty-five outbred male Sprague-Dawley rats (Harlan SpragueDawley, Indianapolis, IN, USA) were housed 4 to 6 per cage. They weighed from 150 to $220 \mathrm{~g}$ each upon receipt and were allowed to acclimate for $1 \mathrm{wk}$ prior to use. Rats were fed a standard diet of Teklad Rat Chow (Harlan Sprague-Dawley, Indianapolis, IN, USA) and water ad libitum and kept on a 12-hour light-dark cycle. The experimental protocols were approved by the Animal Care Use Review Committee at the University of Iowa.

\section{Experimental protocol}

Tooth preparation. The rats were deeply anesthetized with $2.5 \%$ sodium thiopental injected intraperitoneally at a dose of 45 $\mathrm{mg} / \mathrm{kg}$. All cavity preparations were performed by one investigator (KRB) using a modification of previously described procedures (D'Souza et al., 1995). Briefly, animals were placed in an oral restraining rig, and with the aid of a $6-40 x$ dissecting microscope (Zeiss, Frankfurt, Germany), Class V cavity preparations were made on the mesial surface of the maxillary right first molar by means of a high-speed dental handpiece and air coolant. Enamel and dentin were removed until a slight blushing of the dentin appeared, indicating proximity to the pulp tissue. The cavity preparations were etched for $1 \mathrm{~min}$ with $32 \%$ phosphoric acid gel, washed with water, dried, and left unrestored. The contralateral maxillary first molar was used as an unoperated control. The animals were then allowed to recover and were maintained with routine husbandry until their death.

One, 4, or 14 days following cavity preparation, rats were again deeply anesthetized with sodium thiopental and transcardially perfused with $100 \mathrm{~mL}$ saline followed by $400 \mathrm{~mL} 2 \%$ paraformaldehyde in $0.1 \mathrm{M}$ phosphate buffer (PB, $\mathrm{pH} 7.3$ ). The maxillary jaw segments were removed en bloc, post-fixed in $2 \%$ paraformaldehyde for two hr. at $4^{\circ} \mathrm{C}$, and decalcified in a phosphate-buffered ( $\mathrm{pH}=7.0$ ) $10 \%$ ethylenediaminetetraacetic acid (EDTA) solution at $4^{\circ} \mathrm{C}$ for approximately 14 days. After jaw segments were equilibrated in $30 \%$ sucrose for $24 \mathrm{hr}$, cryostat sections $(20 \mu \mathrm{m})$ were cut and stored in $0.1 \mathrm{M} \mathrm{PB}$. We stained representative sections with $H \& E$ to evaluate the presence and extent of inflammation in prepared teeth. Other sections were processed histochemically for NADPH-diaphorase or immunohistochemically for NOS. At a minimum, every tenth serial section was examined by light microscopy, which was increased to at least every third serial section within the region of the cavity preparation.

NADPH-diaphorase. Free-floating sections were incubated in $0.3 \%$ Triton X-100 (Fischer Scientific, Fairlawn, NJ, USA), $1 \mathrm{mg} / \mathrm{mL} \beta-$ $\mathrm{NADPH}$, and $0.5 \mathrm{mg} / \mathrm{mL}$ nitroblue tetrazolium (both from Sigma Chemical Company, St. Louis, MO, USA) in 0.1 M PB (pH 7.4) at $37^{\circ} \mathrm{C}$ for 45 to $75 \mathrm{~min}$ in the dark. The tissues were then transferred to phosphate buffer, mounted on gelatin-coated slides, and air-dried. The slides were dehydrated in a graded series of alcohols $(70 \%, 95 \%, 100 \%$, and $100 \%)$, cleared in xylene, and coverslipped. Sections reacted in the absence of $\beta$-NADPH served as negative controls.

Immunocytochemistry for NOS. Free-floating sections were rinsed in $0.1 \mathrm{M} \mathrm{PB}$ and pre-incubated for $30 \mathrm{~min}$ in $3 \%$ normal goat serum (NGS) in phosphate-buffered saline (PBS) at pH 7.4. To assess the presence of endogenous peroxidase activity, we rinsed some of the sections in $5 \% \mathrm{H}_{2} \mathrm{O}_{2}$ for $10 \mathrm{~min}$ prior to pre-incubation in $3 \%$ NGS. Sections were then incubated for $48 \mathrm{hr}$ at $4^{\circ} \mathrm{C}$ with monospecific polyclonal antibody to macNOS (Kummer et al., 1992) or nNOS (Wilcox et al., 1997) diluted to 1:2000 and $1: 4000$, respectively, in $1 \%$ normal goat serum (NGS, with $0.75 \%$ Triton X-100 in PBS). Following two 10-minute washes in PB, sections were washed with $3 \%$ NGS for $30 \mathrm{~min}$ and incubated for 1 $\mathrm{hr}$ at room temperature with the secondary antibody (biotinylated goat anti-rabbit-IgG; Jackson ImmunoResearch Laboratories, Inc., West Grove, PA, USA) diluted in 1\% NGS with $0.75 \%$ Triton $X-100$. Following two 10 -minute rinses with PBS and a 30 -minute rinse with $3 \%$ NGS, sections were incubated with $\mathrm{ABC}$ solution (peroxidase-conjugated egg-white avidin; 
Jackson Immuno Research Laboratories, West Grove, PA, USA). Reaction products were visualized with diaminobenzidine DAB (0.05\%: Sigma Chemical Co., St. Louis, MO, USA)- $\mathrm{H}_{2} \mathrm{O}_{2}(0.01 \%)$ in $0.1 \mathrm{M} \mathrm{PB}$ for 5 to $10 \mathrm{~min}$. Sections were then rinsed with $\mathrm{PB}$ and mounted, dehydrated, and coverslipped. Sections were reacted without the primary antibody as negative controls for immunoreactivity for both macNOS and nNOS.

\section{Data analysis}

The homogeneous distribution of NADPH-d in the pulp tissue facilitated quantification of stain intensity by digital image analysis. Image analysis has been shown to be a useful tool for quantifying histochemical differences in staining intensity (Picton and Clark, 1978; Blanco et al., 1988) and, in particular, has been used to analyze NADPH-d-reacted sections (Diaz-Arayas et al., 1993). Serial sections were digitized at a magnification of $2.5 \mathrm{X}$ (so that the entire first molar could be visualized) on a Videk Megaplus image acquisition system (Perceptics Corp., Knoxville, TN, USA) and evaluated by aid of computer (Apple Macintosh IIci, Apple Computer, Inc., Cupertino, CA, USA). The output of the video scanner was amplified and digitized into a $1024 \times 1024$ pixel array, such that each pixel had a gray level range of 0 (white) to 255 (black). For each section that was digitized, an empty field image was also digitized. An empty field image is digitally captured by removal of the histologic slide from the microscope's stage while retaining all of the microscope's illumination settings (intensity, aperture, etc.). Subtracting the empty field image from the corresponding histologic-section image reduces measurement artifacts in the gray level values that are caused by unequal microscope illumination across the field of view (Cole and Bond, 1972). Similar morphologic areas of $0.0246 \mathrm{~mm}^{2}(0.1 \mathrm{~mm}=39$ pixels $)$ were assigned in a blinded manner to the distal, middle, and mesial pulp of cavity-prepared and control first molars, and in the central pulp of second molars as an additional uninflamed control. Mean gray level values (MGLVs) were computed for each area.

Representative blood vessels in the mesial root were selected and measured for MGLV and diameter in each group. The blood vessels measured were of homogenous appearance, free of apparent artifact, and perpendicular to the plane of section. Vessels sectioned tangentially, as indicated morphologically by elongation of the vessel wall (see example, Fig. 6), were not included in diameter measurements. Since vessel diameter may be influenced by different orientation of the sections, we attempted to select similarly oriented histologic slides from each group. Histologic slides which included the entire coronal pulp (mesial to distal) and mesial radicular pulp (apical to coronal) were measured. In some cases, it was not possible to obtain adequate sectioning throughout the entire crown and mesial root for image analysis; thus, the number of rats at each time point varies. To assess the reliability of the image analysis in obtaining MGLVs, we re-digitized and re-measured 5 randomly selected sections on separate occasions in a blinded manner. There was no significant difference between the first and second MGLV measurements (paired $t$ test, $\mathrm{p}=0.85$ ).

The heterogeneous distribution pattern of nNOS and macNOS immunoreactivity hampered quantification of stain intensity by digital image analysis. Optimum stain density measurements could not be conducted without biased selection of the area to be measured. Therefore, sections processed for $\mathrm{nNOS}$ and
macNOS immunoreactivity were qualitatively assessed in both prepared and unprepared tooth pulps.

To evaluate changes in NADPH-d reactivity in individual pulps at each time period $(1,4$, or 14 days) following cavity preparation, we calculated a percent change in MGLV: (mesial MGLV - distal MGLV) $\div$ distal MGLV. We then averaged percent changes to determine a mean change in intensity. All results are expressed as mean \pm standard deviation (SD). Mean gray level values were compared by means of a $t$ test or analysis of variance (ANOVA), and, where appropriate, pairwise comparisons were made by Scheffé's test. Statistical differences were considered significant at $p$ values of less than 0.05 .

\section{Results}

\section{Pulp inflammation}

One day after cavity preparation, acute inflammation characterized the mesial pulp horn. Examination of serial sections through the extent of the cavity preparation revealed that pulp adjacent to shallower areas of the cavity preparation contained only disrupted odontoblasts. At the site of the deeper portions of the preparation, inflammatory cells were present, the predominant type being the neutrophil. No evidence of necrosis was present one day after cavity preparation (Fig. 1).

Four days after cavity preparation, inflammatory cells were predominantly of the chronic cell type: macrophages and plasma cells. Neutrophils and polymorphonuclear leukocytes were common but not predominant. Typically, the inflammatory cells coalesced into a distinct 'lesion' which completely obliterated the underlying normal pulpal cell architecture (Fig. 2). Some leukocytic lesions showed areas of focal necrosis centered at the base of dentinal tubules associated with the deepest part of the cavity preparations. A zone of densely packed leukocytes would then surround this necrotic core. Bordering the lesion, the pulp retained a normal histologic appearance except for increased eosinophilic staining of the ground substance and the appearance of occasional extravascular inflammatory cells neighboring distended blood vessels. No evidence of secondary or reparative dentin formation was seen at this time.

An analysis of pulp vessels of the mesial root revealed that there was a significant increase in vessel diameter following tooth preparation (ANOVA, $\mathrm{p}<0.0001$ ). A post hoc Scheffé Ftest of all possible pairwise comparisons showed that at four days after tooth preparation, vessels were significantly larger in diameter than one-day, 14-day, and control animals (Fig. 3).

At 14 days after cavity preparation, histologic presentations were more varied. The most distinguishing features that separated the presentations of 14-day animals from those of four-day animals were the presence and extent of necrosis. All of the inflamed pulps at 14 days contained areas of necrosis. The area of necrosis typically expanded preferentially down the mesial root, leaving the pulp tissue in the distal coronal pulp appearing unaffected. As the extent of necrosis within the inflammatory lesion increased, the area of leukocytic obliteration narrowed to a small band of cells bordering the necrosis (Fig. 4). 


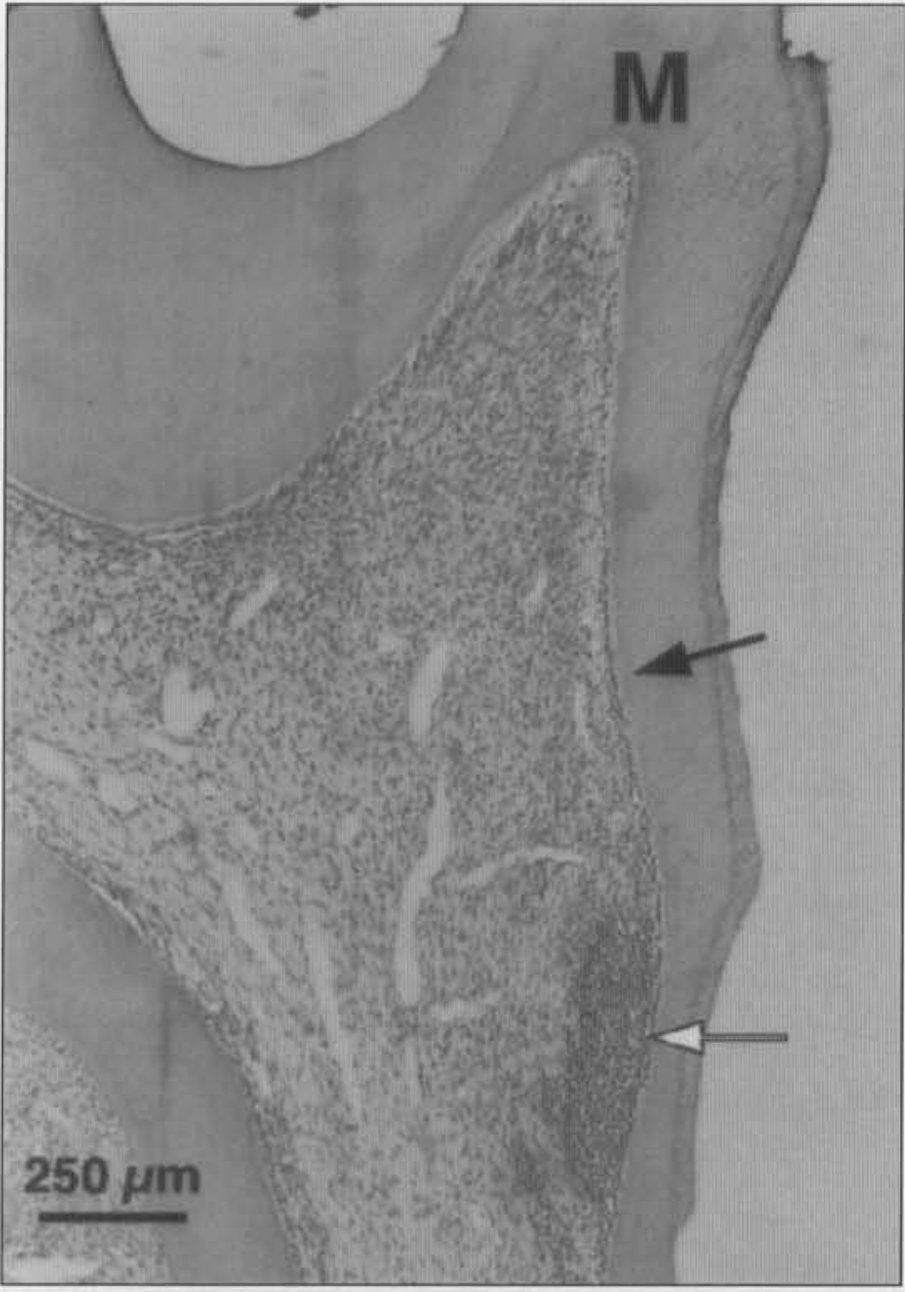

Figure 1. H\&E-stained section of maxillary first molar 1 day following cavity preparation. The area of dentin removal extends from the mesial cusp (M) to the junction of the occlusal and middle thirds of the root. Note that the area of shallower tooth preparation contains only disrupted odontoblasts (black arrow), while the deeper portion of the preparation has a small area of leukocytic infiltration (white arrow).

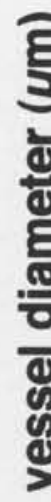

통
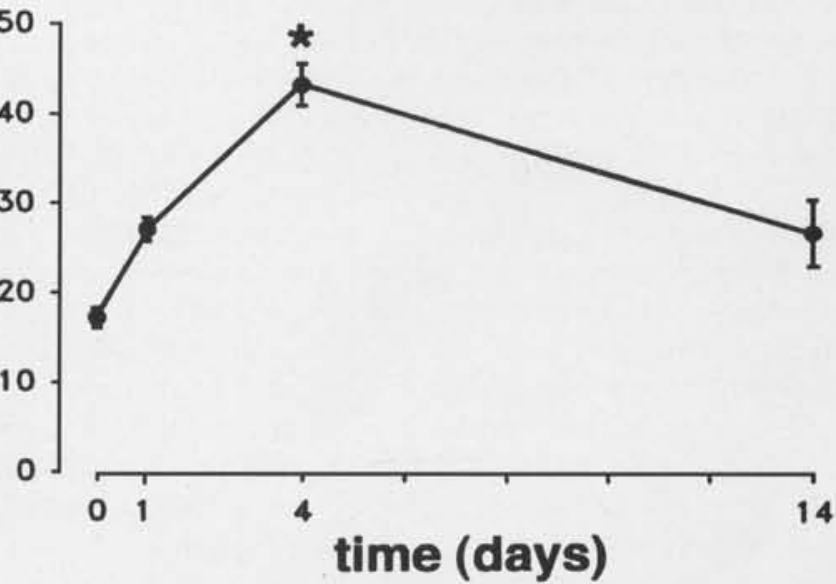

Figure 3. Time course showing change in blood vessel diameter following tooth preparation. * denotes significant difference (ANOVA, p $<0.05$ ) from control represented at time 0 . Error bars are \pm 1 SD.

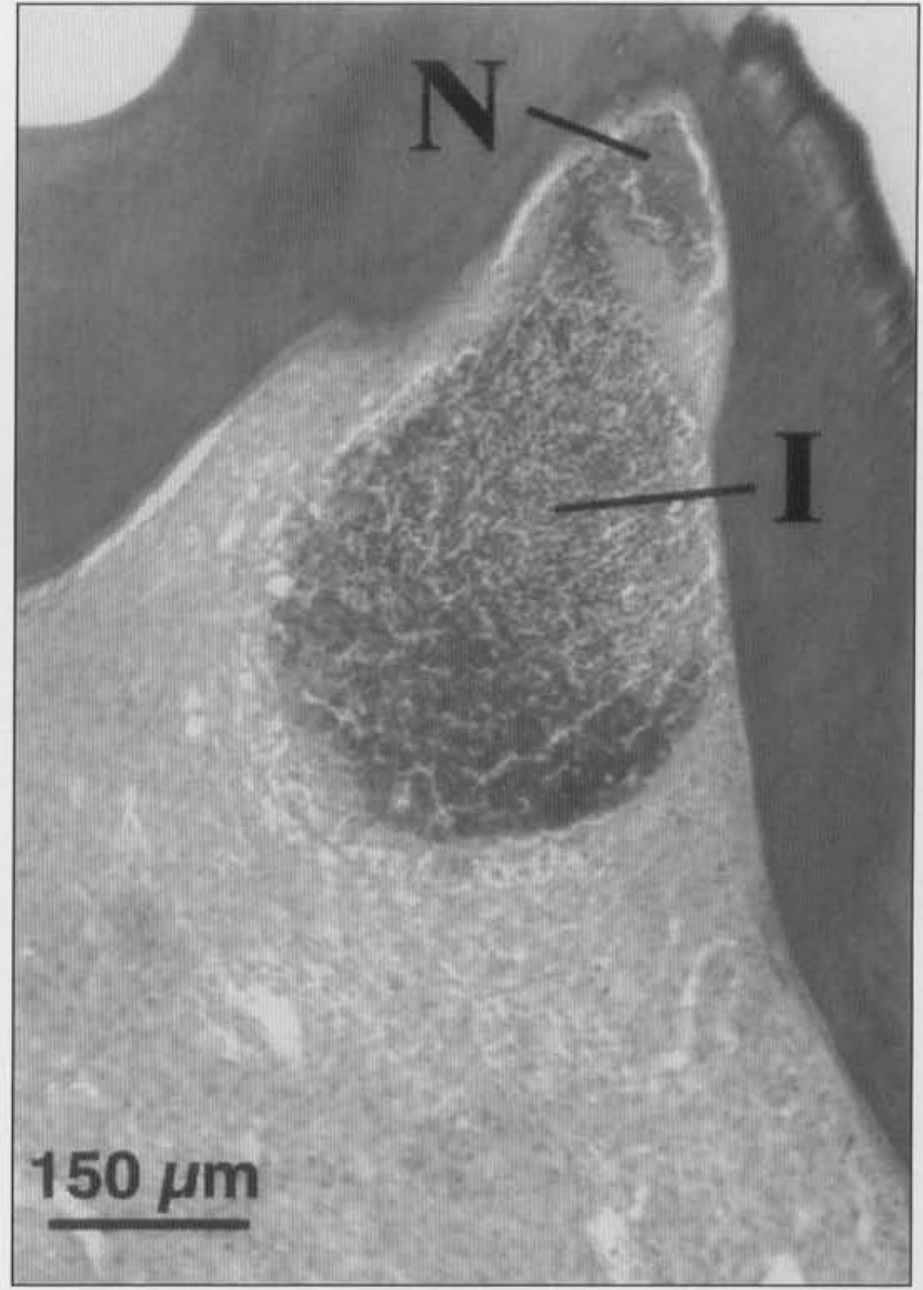

Figure 2. H\&E-stained section of maxillary first molar 4 days following cavity preparation. Note the complete obliteration of the underlying normal pulp by inflammatory cells (I). A small area of necrosis (N) is apparent at the base of the dentinal tubules.

\section{NADPH-d reactivity}

In general, NADPH-d reactivity in the central pulp of control (unprepared) teeth was faint and homogenous, with increased intensity in the peripheral pulp (both sub-odontoblastic and odontoblast cell layers) and blood vessels (Fig. 5). NADPH-d activity was not evident in pulpal nerves. Negative controls, in which sections were reacted in the absence of $\beta-N A D P H$, were without significant NADPH-d reactivity (Fig. 6). These findings are consistent with those reported by Kerezoudis et al. (1993). The Table shows average MGLVs of the mesial pulp, distal pulp, and blood vessels of the mesial root. Analysis of MGLVs in unprepared pulps showed that the mesial pulp and distal pulp did not significantly differ from each other $(53.9 \pm 9.5$ vs. $59.1 \pm 19.3$, respectively; see Table); however, blood vessels in control teeth were significantly darker $(82.4 \pm 7.6)$ than the corresponding mesial and distal pulp areas (ANOVA, $\mathrm{p}<0.05$ ).

The MGLVs for the distal pulp of prepared teeth remained unaffected by the progression of the inflammatory lesion in the mesial pulp with time. Distal pulp MGLVs from unexposed first molars and prepared teeth at each time period (1, 


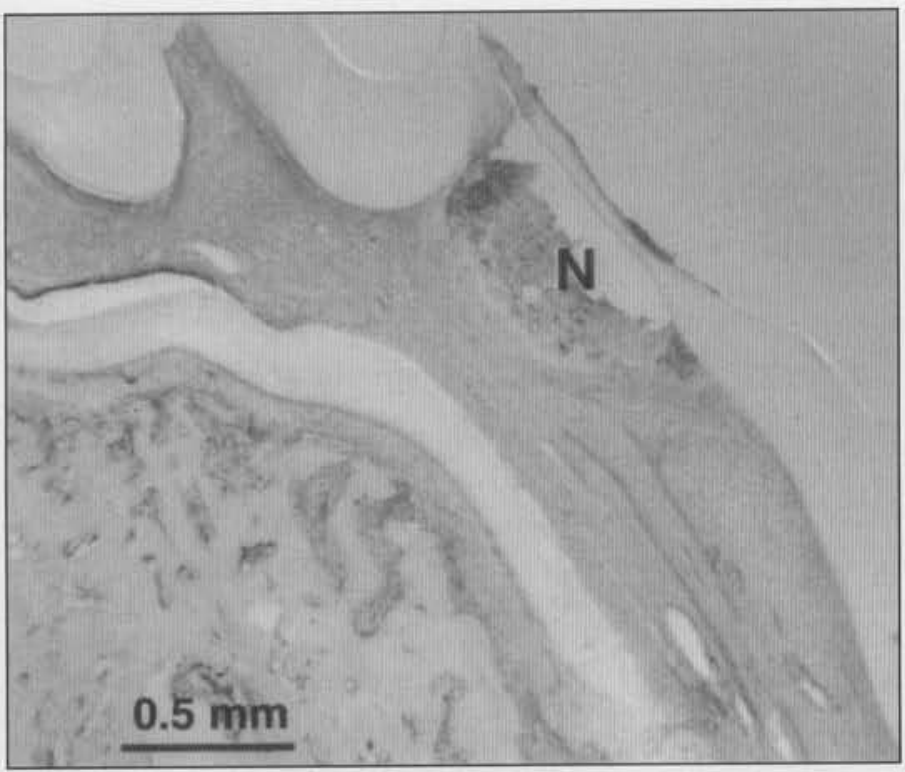

Figure 4. H\&E-stained section of maxillary first molar 14 days following cavity preparation. Leukocytic lesions were typically larger at this time point and contained proportionally more necrosis $(\mathrm{N})$ within the lesion.

4 , and 14 days after preparation) were not significantly different (Table). Average MGLVs of distal pulp from the first molar and mesial pulp from the unprepared second molar were also compared and were found not to differ significantly (data not shown).

One day after cavity preparation, a slight increase in NADPH-d localization was observed in the pulp tissue adjacent to the prepared dentin. As in pulp tissue from unprepared teeth, and consistent at all periods after tooth preparation, NADPH-d activity was not present in pulpal nerves. Blood vessels were more intensely stained in the mesial root (Fig. 7). A comparison of the mean mesial pulp and distal pulp MGLVs showed that cavity preparation did not result in significantly increased NADPH-d intensity in pulp tissue after one day. However, MGLVs of blood vessels adjacent to the prepared surface were significantly increased when compared with both mesial pulp and control blood vessel MGLVs (Table).

At 4 days after cavity preparation, all teeth demonstrated areas of leukocytic infiltration adjacent to the prepared region of dentin. There was a statistically significant increase in NADPH-d intensity in the mesial pulp area immediately surrounding the leukocytic infiltration (Fig. 8, Table). Blood vessels of the mesial pulp and root which supplied the inflamed area also showed a statistically significant increase in NADPH-d intensity (Table).

Fourteen days after cavity preparation, all prepared teeth showed areas of necrosis within the inflammation. The area inflamed was larger in the 14-day animals than in the four-day animals, with preferential expansion down the mesial root while sparing the distal portion of the coronal pulp (Fig. 9). In some teeth, the area of necrosis reached the apical third of the root. The vessels in the remaining viable pulp tissue surrounding the inflammation displayed more intense NADPH-d reactivity than at any previous time period following cavity
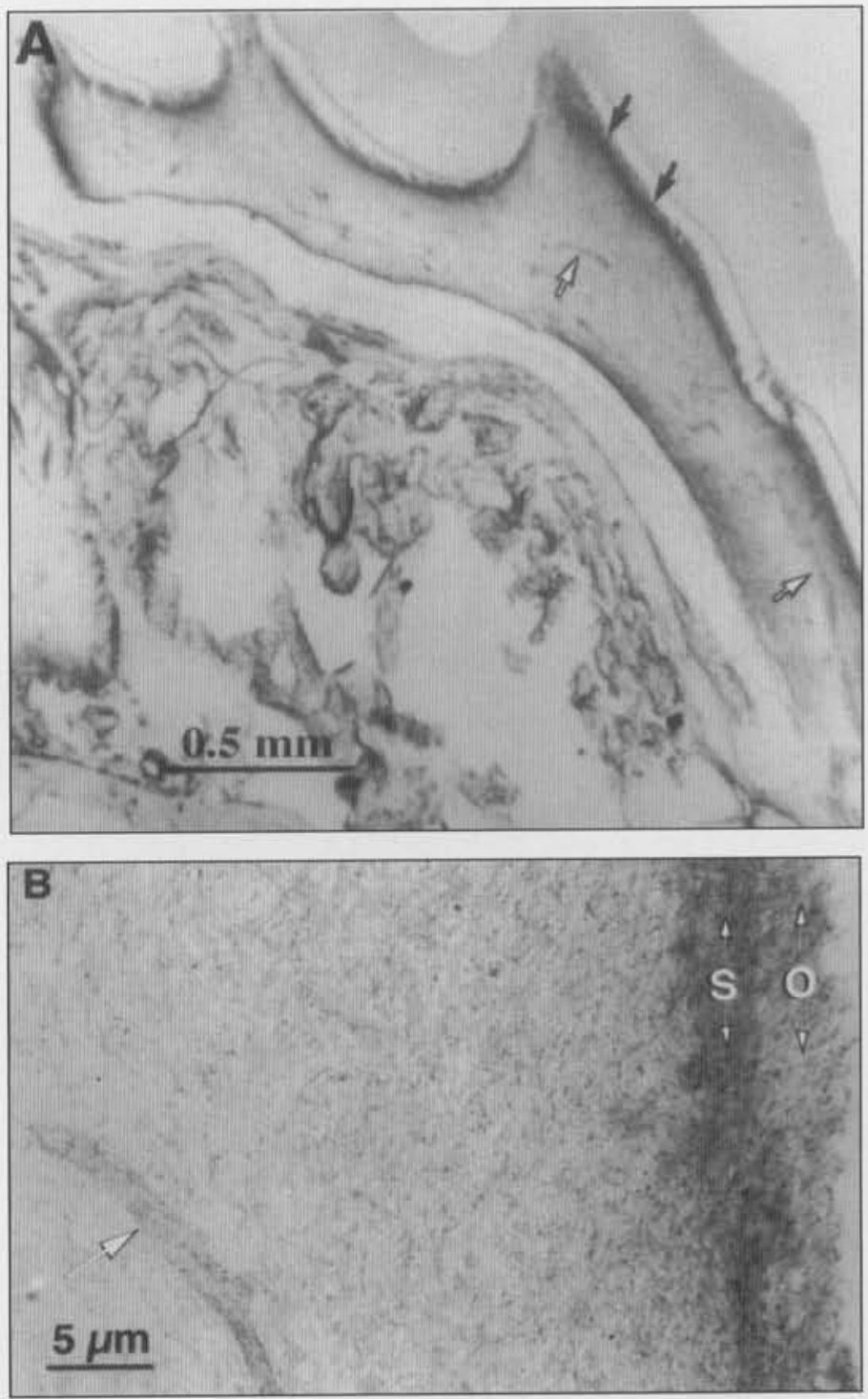

Figure 5. Control (unprepared) maxillary first molar reacted for NADPH-d activity. (A) Staining was fairly homogeneous, with increased intensity in the peripheral pulp (black arrows) and pulp vessels (white arrows). (B) Peripheral pulp and blood vessel (white arrow) from mesial coronal pulp enlarged from (A). Note increased NADPH-d reactivity in the regions corresponding to the odontoblast (O) and subodontoblast (S) layers.

preparation (MGLV $=121.3 \pm 14.7$ ). Interestingly, as the proportional area of necrosis within the inflammatory lesion increased, intense NADPH-d reactivity in pulp tissue between the inflammation and the distal pulp narrowed, with only a small band of increased NADPH-d intensity separating the area of necrosis from the uninflamed-appearing portion of the distal pulp (Fig. 9). A comparison of MGLVs from the remaining pulp, outside this narrow band of inflammatory cells, and the distal pulp revealed no significant difference in intensity $(59.7 \pm 12.5$ vs. $51.2 \pm 13.9$, respectively; Table).

\section{NOS immunoreactivity}

No apparent $\mathrm{nNOS}$ immunoreactivity was identified in pulp tissue of either unprepared (controls) or prepared (inflamed) teeth. 


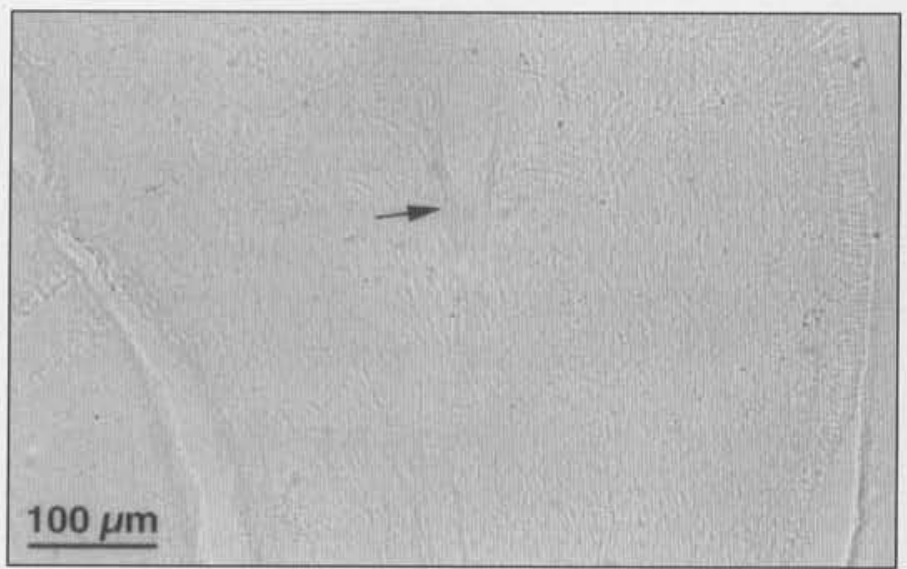

Figure 6. Negative control for NADPH-d staining in the absence of $\beta$-NADPH 4 days following cavity preparation. Partial tangential section through large vessel shows a general lack of staining of the vessel wall (arrow) as well as in surrounding pulp.

In the unprepared teeth, macNOS immunoreactivity was faint to non-apparent in the central pulp tissue. However, there was a slight localization of reactivity in the peripheral pulp of these teeth (Fig. 10) in a pattern strikingly similar to that seen in the unprepared teeth reacted for NADPH-d (compare with Fig. 5A). Negative controls, in which sections were reacted in the absence of the primary antibody, were without significant immunoreactivity (Fig. 11).

In the pulps of inflamed teeth, the distribution of macNOS immunoreactivity again displayed a pattern similar to the distribution of NADPH-d activity, with an increase in intensity in pulp tissue adjacent to the area of dense leukocytic infiltration (Fig. 12). However, macNOS immunoreactivity differed from NADPH-d activity in that macNOS did not label blood vessels in either control or inflamed pulps.

\section{Discussion}

In the tooth pulp, inflammation is characterized by changes in blood flow, immunocompetent cell function, and neural activity. With its demonstrated involvement in these processes as well as cardiovascular and immune functions, one of the potential primary players in the inflammatory response is NO. NADPH-d reactivity has been shown to localize NOS in neuronal and non-neuronal tissues (Hope et al., 1991; Janssens et al., 1992; Lamas et al., 1992; Poeggel et al., 1992; Fischer et al., 1993) and has been shown specifically in tooth pulp (Kerezoudis et al., 1993b). Therefore, we used NADPH-d, in addition to NOS immunoreactivity, to characterize the distribution of NOS in uninflamed and inflamed rat pulp tissue.

NADPH-d reactivity in vessels of uninflamed pulp was consistent with that in other tissues. Molecular cloning has been used to demonstrate a constitutive isoform of NOS in endothelium (Janssens et al., 1992; Lamas et al., 1992; Sessa et al., 1992), and NADPH-d activity has been shown to be distributed in blood vessels in rat brain vasculature (Poeggel et al., 1992; Gabbott and Bacon, 1993). In blood vessels, NO is believed to cause vasodilatation by increasing binding to the

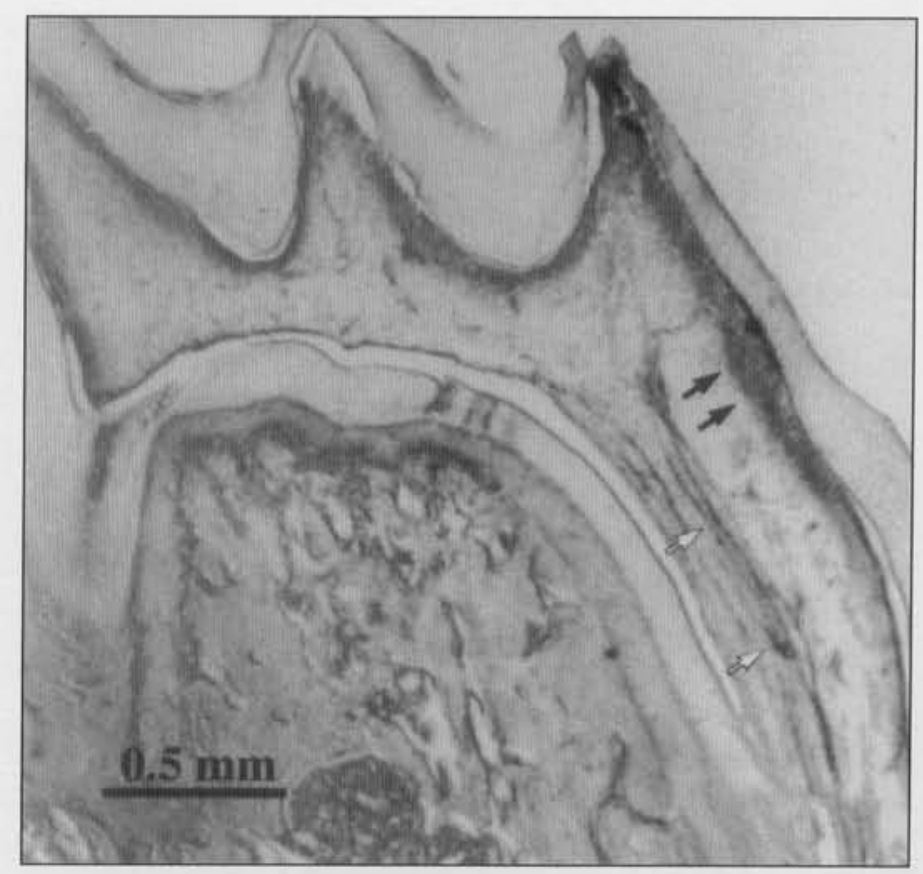

Figure 7. Maxillary first molar reacted for NADPH-d activity 1 day following cavity preparation. Note increased NADPH-d intensity in the pulp tissue adjacent to the prepared dentin (black arrows) and in blood vessels of mesial root (white arrows); however, only the blood vessels had statistically significantly increased intensity as compared with controls (see Table).

heme moiety on soluble guanylate cyclase in smooth-muscle cells, thus increasing intracellular cGMP, which results in relaxation of the smooth-muscle cell (Ignarro et al., 1987).

The presence of NADPH-d reactivity in pulpal vessels is consistent with the role of $\mathrm{NO}$ as an effector in blood flow regulation. Indeed, systemic infusion of the NOS inhibitor $\mathrm{N}^{\mathrm{G}}$-nitro-l-arginine methyl ester (L-NAME) has been shown significantly to reduce basal blood flow in the rat mandibular incisor pulp (Kerezoudis et al., 1993a) and the cat mandibular canine (Lohinai et al., 1995). Further, administration of the nitric oxide donor 3-morpholinosydnonimine (SIN-1) significantly decreased pulpal vascular resistance in the cat mandibular canine (Lohinai et al., 1995).

An alternative explanation for the NADPH-d activity in pulpal vessels is the presence of nNOS in nerves which are in the vicinity of vessels (Bredt et al., 1991; Iadecola et al., 1993). Using NADPH-d as a marker for nNOS in the mouse, Grozdanovic et al. (1992) showed that NADPH-d activity was found in paravascular nerve fibers in several structures, including the tongue and salivary glands; however, we were unable to demonstrate significant NADPH-d, macNOS, or nNOS reactivity in rat pulpal nerves.

That NADPH-d and NOS reactivities were not observable in nerves in rat tooth pulp is of interest because of their identification in other peripheral nerves (Dawson et al., 1991; Fischer et al., 1993) and in pulpal nerves of the cat and dog (Lohinai et al., 1997). NADPH-d activity has been demonstrated in the trigeminal nucleus (Aimi et al., 1991) and nerves innervating other oral structures (Grozdanovic et al., 1992). Recently, the presence of a small number of NADPH-d-posi- 


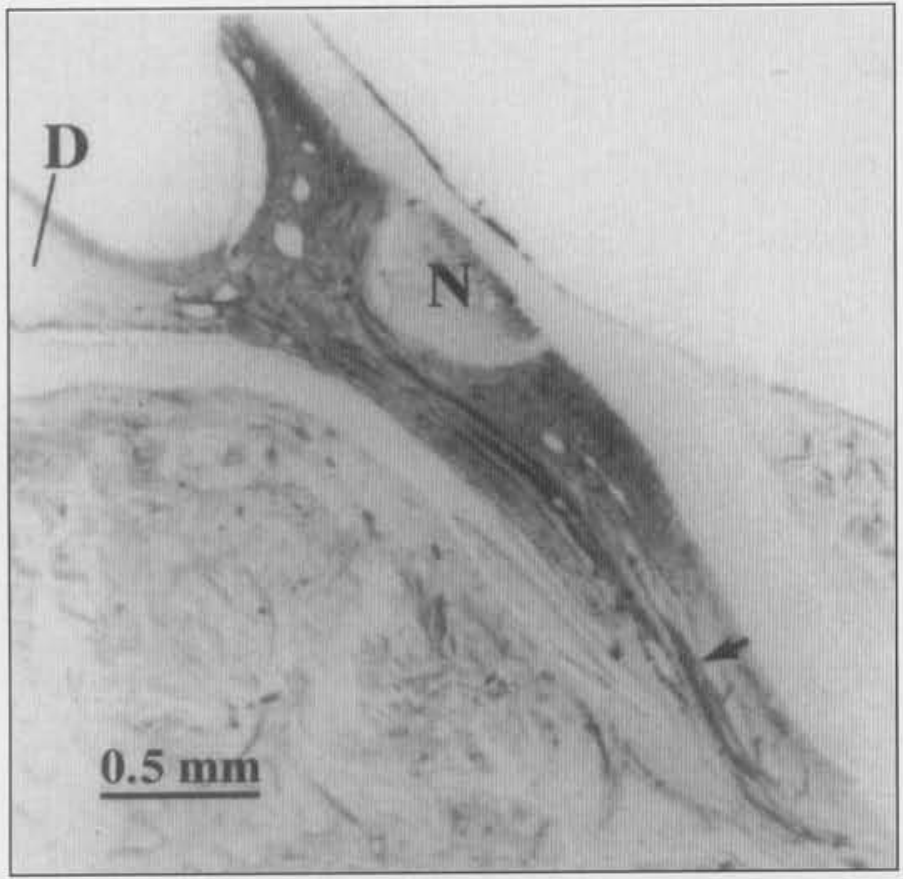

Figure 8. Maxillary first molar reacted for NADPH-d activity 4 days following cavity preparation. Note that an area of leukocytic infiltration and necrosis $(\mathrm{N})$ has developed in the mesial pulp under the prepared dentin. This area is surrounded by pulp tissue with significantly increased NADPH-d intensity in the mesial pulp horn as well as in the mesial root, while the NADPH-d intensity of the distal pulp (D) has remained at control values. Blood vessels (arrow) of the mesial root also had significantly increased NADPH-d intensity (see Table).

tive and/or NOS immunoreactive perivascular and solitary varicose axons in the dental pulp of cats and dogs has been described (Lohinai et al., 1997). This finding is in contrast to results of the present study and to those of Kerezoudis et al. (1993b). This difference might reflect interspecies differences (Uddman et al., 1980) or, alternatively, the use of different methods, since Lohinai's group did not decalcify the tissue as was done in the Kerezoudis and the present studies.

In an attempt to demonstrate that our decalcification process did not affect immunoreactivity of nervous tissue, we reacted decalcified molar sections with antibodies against CGRP and neuropeptide Y (NPY) [1:80,000 (Peninsula Laboratories, Inc., Belmont, CA, USA) and 1:1000 (Accurate Antibodies, Westbury, NY, USA), respectively], both of which have been used to identify nerves in pulp tissue (Silverman and Kruger, 1987; Oswald and Byers, 1993). In our sections, nerve fibers were demonstrated with each of these antibodies. In addition, sections of trigeminal ganglion and brainstems containing trigeminal nucleus (both of which have NADPH-d- and nNOS-labeled neurons) were subjected to our decalcification procedures and retained NADPH-d and nNOS reactivity (data not shown). Therefore, we believe that it is unlikely that the lack of neural staining in the

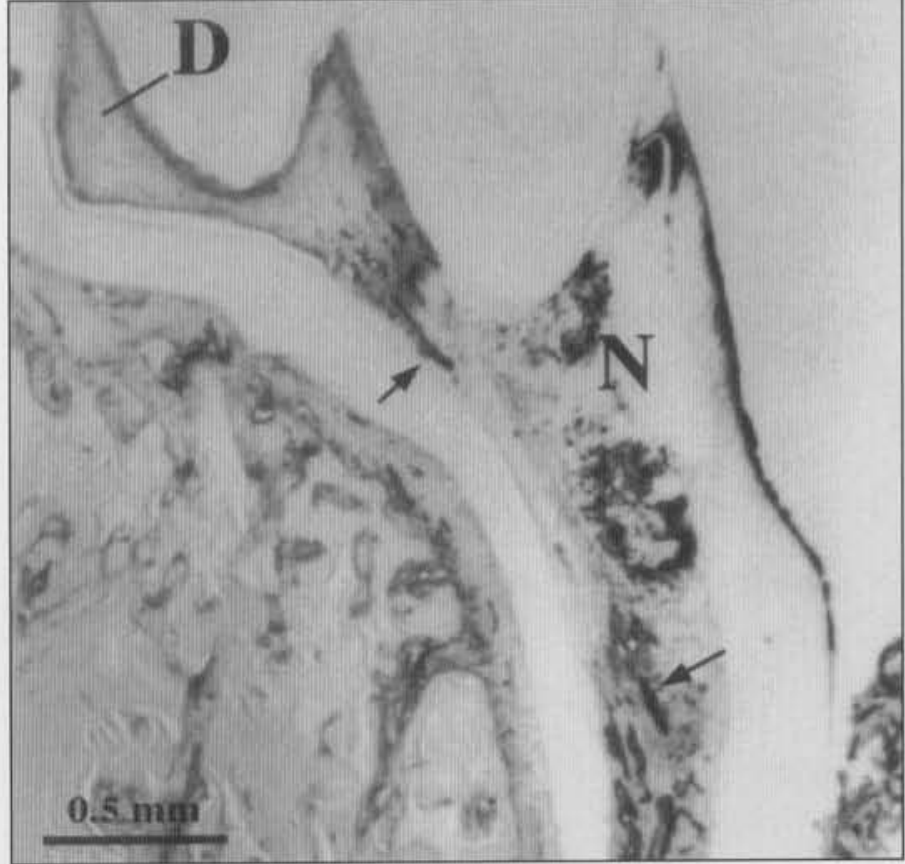

Figure 9. Maxillary first molar reacted for NADPH-d activity 14 days following tooth preparation. The area of necrosis $(\mathrm{N})$ has spread down the mesial root. The blood vessels in the remaining mesial pulp and mesial root show increased NADPH-d reactivity (arrows). The NADPH-d reactivity in the remaining pulp tissue surrounding the necrosis has become less prominent as compared with the four-day post-preparation animals (compare with Fig. 8), while the NADPH-d reactivity of the distal pulp (D) remained at control values (see Table).

pulp is due to our decalcification process. However, the limited number and course of NADPH-d- and/or NOS-positive pulpal nerves reported in the cat and the dog (Lohinai et al., 1997) implies a fragility or, at least, a technique sensitivity that may require further investigation in the rat before their presence in the pulp can be totally ruled out.

Interspecies differences may also account for the lack of pulp neuronal NOS immunoreactivity in the rat compared with that reported in the cat and the dog (Lohinai et al., 1997). In rat dental pulp, no vasoactive intestinal polypeptide (VIP) nerves are present, as opposed to the dental pulp of other mammalian species (Uddman et al., 1980). The macNOS

Table. Comparison of NADPH-d intensity in inflamed and control pulp and blood vessels

\begin{tabular}{ccccc}
\hline $\begin{array}{c}\text { Days after } \\
\text { Tooth Preparation }\end{array}$ & Mesial Pulp & Distal Pulp & $\begin{array}{c}\text { Blood Vessels } \\
\text { in Mesial Root }\end{array}$ & $\mathrm{n}$ \\
\hline 1 & $60.9 \pm 10.8$ & $58.1 \pm 18.3$ & $91.6 \pm 18.3^{\mathrm{b}, \mathrm{c}}$ & 9 \\
4 & $68.1 \pm 19.6^{\mathrm{a}}$ & $54.9 \pm 16.9$ & $108.7 \pm 30.5^{\mathrm{b}, \mathrm{c}}$ & 11 \\
14 & $59.7 \pm 12.5$ & $51.2 \pm 13.9$ & $121.3 \pm 14.7^{\mathrm{b}, \mathrm{c}}$ & 5 \\
Control (unprepared) & $53.9 \pm 9.5$ & $59.1 \pm 19.3$ & $82.4 \pm 7.6^{\mathrm{d}}$ & 10 \\
\hline
\end{tabular}

The results are reported as Mean Grey Level Values (MGLV \pm SD) on a scale where $0=$ white and 255 = black (i.e., the higher the MGLV, the greater the NADPH-d stain intensity).

a Significantly different from distal pulp of inflamed teeth and mesial and distal pulp of control teeth, $\mathrm{p}<0.05$.

b Significantly different from mesial pulp in inflamed teeth, $\mathrm{p}<0.05$.

c Significantly different from blood vessels in control tooth, $\mathrm{p}<0.05$.

d Significantly different from mesial and distal pulp in both inflamed and control teeth, $\mathrm{p}<0.05$. 


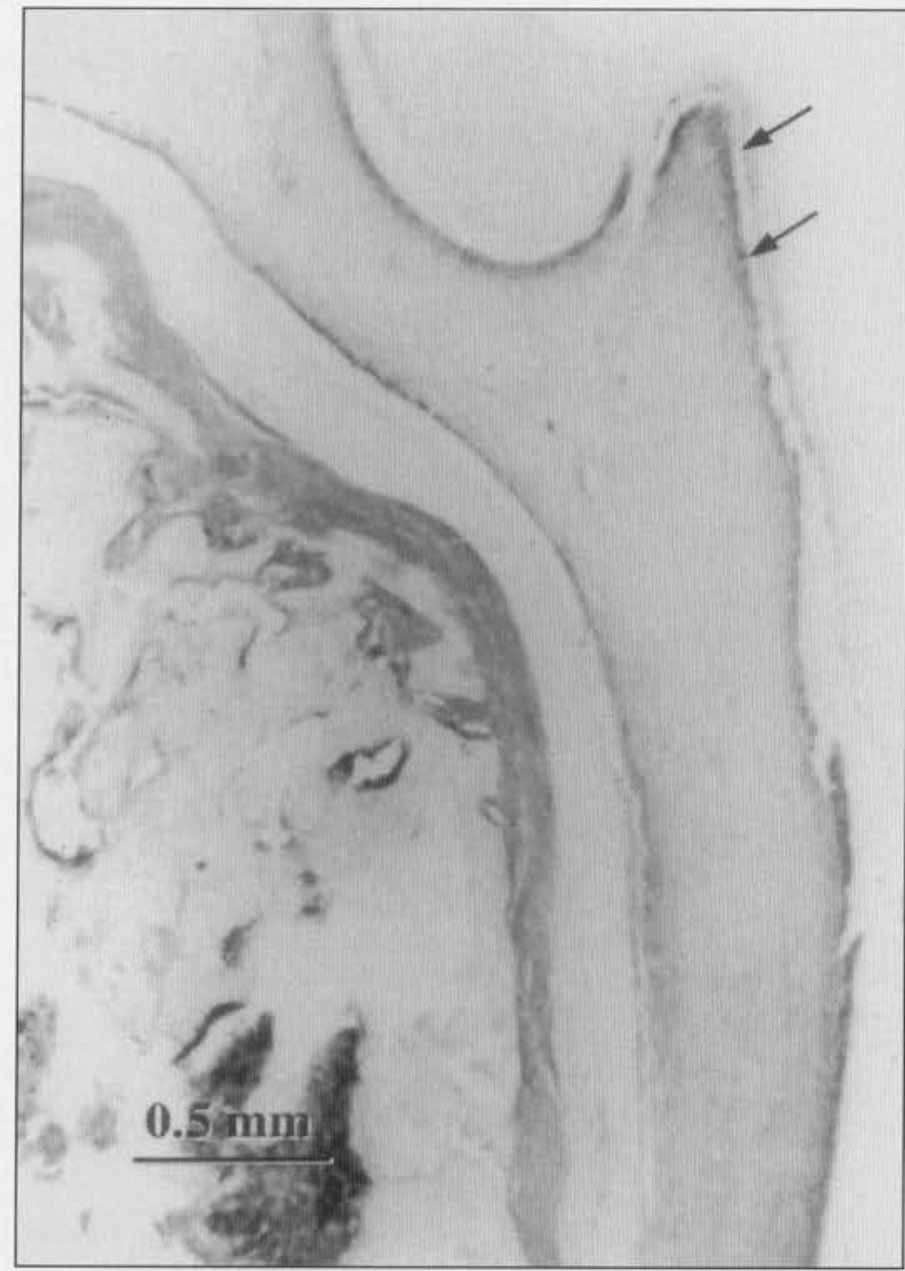

Figure 10. Control (unprepared) maxillary first molar reacted for macNOS immunoreactivity. In a distribution pattern similar to that of control teeth reacted for NADPH-d (Fig. 5A), staining was fairly homogenous, with increased intensity in the peripheral pulp (arrows). Note, however, the absence of macNOS immunoreactivity in pulpal blood vessels.

(Kummer et al., 1992) and nNOS (Wilcox et al., 1997) antibodies used in the present study are well-characterized. Previously, perivascular nerve fibers of blood vessels in the guinea pig were demonstrated by means of the macNOS antibody that was also used in the present study. Interestingly, double-labeling techniques allowed these NOS-containing nerve fibers to be identified as belonging to the VIP/acetylcholine-containing class, whereas noradrenergic and substance-P-containing perivascular fibers were devoid of NOS (Kummer et al., 1992). If this premise is correct, the NOS-reactive nerves described in cat and dog pulp (Lohinai et al., 1997) may belong to the VIP-containing class not found in the rat.

The increase in NADPH-d intensity in blood vessels following tooth preparation is consistent with findings which show that, under inflammatory conditions, there may be induction of NOS-like activity in endothelium (Kilbourn and Bellone, 1990) and vascular smooth muscle (Busse and Mulsch, 1990; MacNaul and Hutchinson, 1993). Using Northern hybridizations, investigators have showed increased levels of inducible NOS mRNA in human aortic smooth mus-

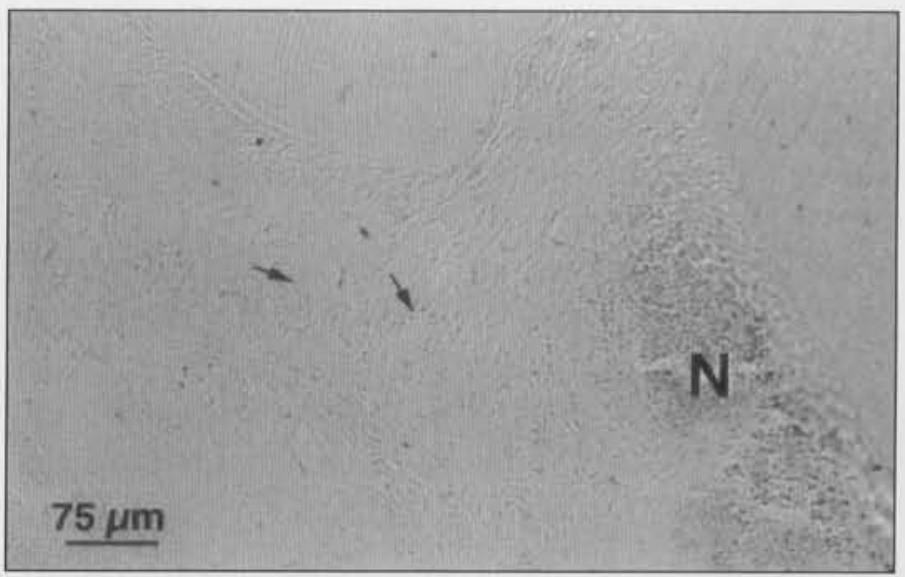

Figure 11. Negative control for macNOS immunoreactivity in the absence of the primary antibody 4 days following cavity preparation. Note lack of staining in the vessels (arrows) and surrounding central pulp adjacent to a large leukocytic lesion filled with necrotic debris (N).

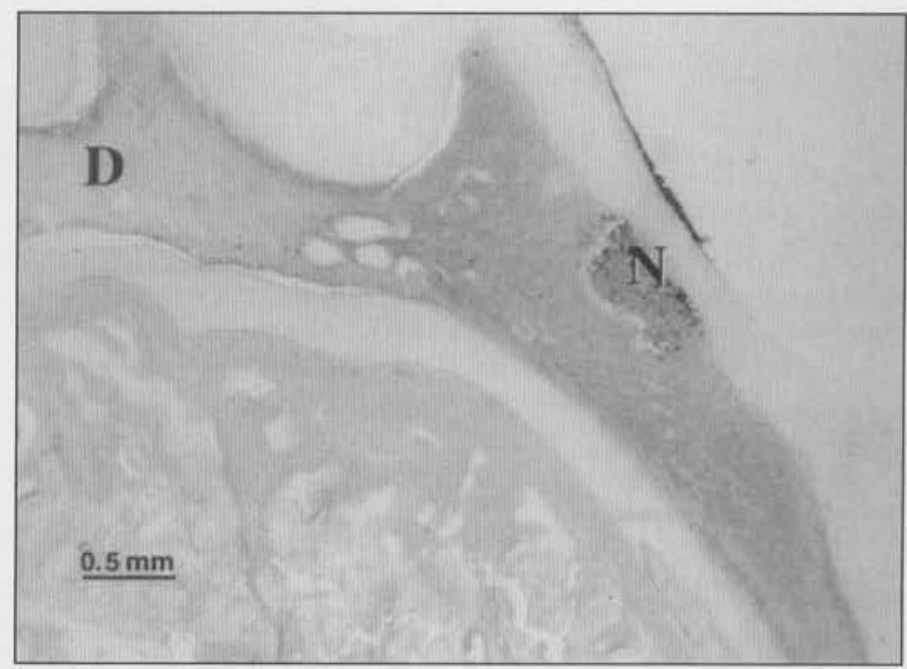

Figure 12. Maxillary first molar reacted for macNOS immunoreactivity 4 days following cavity preparation. An area of leukocytic infiltration and necrosis $(N)$ has developed in the mesial pulp under the prepared dentin. This area is surrounded by pulp tissue with increased macNOS immunoreactivity in a distribution pattern similar to that seen in inflamed pulp reacted for NADPH-d (see Fig. 8). Note, however, that the lack of macNOS immunoreactivity in blood vessels differs dramatically from inflamed teeth reacted for NADPH-d. $\mathrm{D}=$ distal pulp.

cle following treatment with the cytokines interleukin $1 \beta$, tumor necrosis factor $\alpha$, interferon $\gamma$, and lipopolysaccharide (MacNaul and Hutchinson, 1993). Presumably, the increase in message for NOS, and the resultant increase in NOS content in the vessels, might lead to an increase in NADPH-d intensity. The presence of two distinct isoforms of NOS in the vasculature has led to a proposed mechanism in which vascular tone can be regulated under normal conditions (i.e., via a constitutive form of NOS), leading to a decreased ability of vessels to respond to neurotransmitters or blood-borne vascular mediators (via an inducible form of NOS) under inflammatory conditions (Kilbourn and Bellone, 1990; Kilbourn et al., 1990).

Of interest was an increase in NADPH-d intensity in pul- 
pal cells surrounding the core of leukocytic infiltration. There are several candidates for a source of inducible NOS in inflamed tissue, such as would be present following pulpal inflammation. In the rat, cells which have been identified as having inducible NOS protein or iNOS-like activity include smooth-muscle cells, endothelial cells, fibroblasts, and inflammatory cells such as neutrophils and monocytes/ macrophages (Nussler and Billiar, 1993). In contrast to constitutive forms of NOS, inducible NOS is not present under normal conditions. This is consistent with our findings that neither significant NADPH-d nor macNOS activity was present in the central pulp of control teeth. Upon stimulation with appropriate agents (such as the cytokines interferon- $y$, tumor necrosis factor, interleukin-1, and/or lipopolysaccharide), fibroblasts, neutrophils, and macrophages can be induced to express iNOS. A time course for the induction of iNOS mRNA in rat hepatocytes following incubation with inflammatory cytokines plus lipopolysaccharide showed that iNOS mRNA was present in the cells 6 hrs after exposure and was still present 48 hrs after exposure (Nussler and Billiar, 1993).

In the present study, increased NADPH-d intensity was seen in the pulp tissue surrounding the core of dense leukocytic infiltration at one day following cavity preparation, and was observable at all times, extending out to 14 days after preparation. In addition, macNOS reactivity was observed in a distribution similar to that of NADPH-d in the pulp surrounding the core of inflammation, with the exception that macNOS was not seen in pulpal blood vessels. These results are consistent with the induction of NOS as a result of pulpal inflammation. Because macNOS-like activity has been shown to be present in inflammatory neutrophils (McCall et al., 1991), macrophages (Hibbs et al. 1987; Stuehr et al., 1991), and fibroblasts (Werner-Felmayer et al., 1990; Willis et al. 1994), it is unclear which of these cells is associated with the increase in macNOS activity in the pulp. However, the distribution of both NADPH-d and macNOS beyond the core of leukocytic cells into the surrounding pulp tissue suggests that pulpal cells in addition to inflammatory cells are involved. The role of macNOS in inflammation appears to be complex. Macrophage-derived NO has been shown to inhibit microbes (Nathan and Hibbs, 1991) as well as lymphocytes (Albina and Henry, 1991). Thus, NO may serve as an antimicrobial agent, as well as an immune regulator.

In conclusion, we found the presence of NADPH-d and macNOS reactivity in pulpal cells, NADPH-d reactivity alone in pulpal blood vessels, and neither NADPH-d, macNOS, nor nNOS activity in pulpal nerves in the rat. Although we demonstrated an increase in NADPH-d and macNOS reactivity in the pulp due to inflammation, this increased activity lacked apparent neuronal NOS contribution. Therefore, we suggest that NO mediates the pulpal inflammatory response through its affects on the paralesional pulp tissue and surrounding endothelial/vascular structures.

\section{Acknowledgments}

We thank Drs. Bernd Mayer and Dave Harrison for their generous gifts of polyclonal antibodies to macNOS and nNOS, respectively. This research was supported in part by
NIH Grant No. DA02879 and a pain research award from Bristol Myers Squibb Co (G.F.G.). A.S.L. was supported by a Dentist-Scientist Award, NIH Grant No. DE00175-09. K.R.B. was supported in part by an Endodontic PhD Support Grant from the American Association of Endodontists and the American Dental Association Health Foundation New Dentist Scientist Awards.

\section{References}

Ahlberg KF (1978). Influence level of noxious heat stimulation on sensory nerve activity in the feline tooth pulp. Acta Physiol Scand 103:71-80.

Aimi Y, Fujimura M, Vincent SR, Kimura H (1991). Localization of $\mathrm{NADPH}$-diaphorase-containing neurons in sensory ganglia of the rat. J Comp Neurol 306:382-392.

Albina JE, Henry WL Jr (1991). Suppression of lymphocyte proliferation through the nitric oxide synthetase pathway. I Surg Res 50:403-409.

Ashwal S, Cole DJ, Osborne TN, Pearce WJ (1994). Dual effects of L-NAME during transient focal cerebral ischemia in spontaneously hypertensive rats. Am J Physiol 267:H276-H284.

Bergenholtz G, Ahlsted S, Lindhe J (1977). Experimental pulpitis in immunized monkeys. Scand J Dent Res 85:396-406.

Bergenholtz G, Nagaoka S, Jontell M (1991). Class II antigen presenting cells in experimentally induced pulpitis. Int Endodont J 24:8-14.

Blanco CE, Sieck GC, Edgerton VR (1988). Quantitative histochemical determination of succinic dehydrogenase activity in skeletal muscle fibbers. Histochem J 20:230-243.

Bredt DS, Hwang PM, Snyder SH (1990). Localization of nitric oxide synthase indicating a neural role for nitric oxide. Nature 347:768-770.

Bredt DS, Glatt CE, Hwang PM, Fotuhi M, Dawson TM, Snyder SH (1991). Nitric oxide synthase protein and mRNA are discretely localized in neuronal populations of the mammalian CNS together with NADPH diaphorase. Neuron 7:615-624.

Brodin E, Gazelius B, Olgart L, Nilsson G (1981). Tissue concentration and release of substance P-like immunoreactivity in the dental pulp. Acta Physiol Scand 111:141-149.

Busse R, Mulsch A (1990). Induction of nitric oxide synthase by cytokines in vascular smooth muscle cells. FEBS Lett 275:8790.

Cole M, Bond CP (1972). Recent advances in automatic image analysis using a television system. J Microsc 96:89-96.

D'Souza RN, Bachman T, Baumgardner KR, Butler WT, Litz M (1995). Characterization of cellular responses involved in reparative dentinogenesis in rat molars. J Dent Res 74:702709.

Dawson TW, Bredt DS, Fotuhi M, Hwang PM, Snyder SH (1991). Nitric oxide synthase and neuronal NADPH diaphorase are identical in brain and peripheral tissues. Proc Natl Acad Sci USA 88:7797-7801.

DelBalso AM, Nishimura RS, Setterstrom JA (1976). The effects of thermal and electrical injury on pulpal histamine levels. Oral Surg 41:110-113.

Diaz-Araya CM, Provis JM, Billson FA (1993). NADPHdiaphorase histochemistry reveals cone distributions in adult 
human retinae. Aust NZ J Ophthalmol 21:171-179.

Fischer A, Mundell P, Mayer B, Preissler U, Philippin B, Kummer W (1993). Nitric oxide synthase in guinea pig lower airway innervation. Neurosci Lett 149:157-160.

Gabbott PLA, Bacon SJ (1993). Histochemical localization of NADPH dependent diaphorase (nitric oxide synthase) activity in vascular endothelial cells in the rat brain. Neuroscience 57:79-95.

Gazelius B, Edwall B, Olgart L, Lundberg JM, Hokfelt T, Fischer JA (1987). Vasodilatory effects and coexistence of calcitonin gene-related peptide (CGRP) and substance $P$ in sensory nerves of cat dental pulp. Acta Physiol Scand 130:33-40.

Grozdanovic Z, Baumgarten HG, Bruning G (1992). Histochemistry of NADPH-diaphorase, a marker for neuronal nitric oxide synthase, in the peripheral autonomic nervous system of the mouse. Neuroscience 48:225-235.

Grutzner EH, Garry MG, Hargreaves KM (1992). Effect of injury on pulpal levels of immunoreactive substance $P$ and immunoreactive calcitonin gene-related peptide. $J$ Endodont 18:553-577.

Hahn CL, Falkler WA Jr, Siegel MA (1989). A study of T and B cells in pulpal pathosis. J Endodont 15:20-26.

Hibbs JB Jr, Taintor RR, Vavrin Z, Rachlin EM (1987). Nitric oxide; a cytotoxic activated macrophage effector molecule. Biochem Biophys Res Commun 157:87-94.

Hirafuji M, Ogura Y (1987). 5-Hydroxytryptamine stimulates the release of prostacyclin but not thromboxane $\mathrm{A} 2$ from isolated rat dental pulp. Eur J Pharmacol 136:433-436.

Hirafuji M, Satoh S, Ogura Y (1980). Prostaglandins in rat pulp tissue. J Dent Res 59:1535-1540.

Hirafuji M, Terashima K, Satoh S, Ogura Y (1982). Stimulation of prostaglandin E2 biosynthesis in rat dental pulp explants in vitro by 5-hydroxytryptamine. Arch Oral Biol 27:961-964.

Hope BT, Michael GJ, Knigge KM, Vincent SR (1991). Neuronal NADPH diaphorase is a nitric oxide synthase. Proc Natl Acad Sci USA 88:2811-2814.

Iadecola C, Beitz AJ, Renno W, Xu X, Mayer B, Zhang F (1993). Nitric oxide synthase-containing neural processes on large cerebral arteries and cerebral microvessels. Brain Res 606:148-155.

Ignarro LJ, Buga GM, Wood KS, Byrns RE, Chaudhuri G (1987). Endothelium-derived relaxing factor produced and released from artery and vein is nitric oxide. Proc Natl Acad Sci USA 84:9265-9269.

Janssens SP, Shimouchi A, Quertermous T, Bloch DB, Bloch KD (1992). Cloning and expression of a cDNA encoding human endothelium-derived relaxing factor/nitric oxide synthase. $J$ Biol Chem 267:14519-14522.

Kerezoudis NP, Olgart L, Edwall L (1993a). Differential effects of nitric oxide synthesis inhibition on basal blood flow and antidromic vasodilation in rat oral tissues. Eur J Pharmacol 241:209-219.

Kerezoudis NP, Olgart L, Fried K (1993b). Localization of NADPH-diaphorase activity in the dental pulp periodontium and alveolar bone of the rat. Histochemistry 100:319-322.

Khayat BG, Byers MR, Taylor PE, Mecifi K, Kimberly CL (1988). Responses of nerve fibers to pulpal inflammation and periapical lesions in rat molars demonstrated by calcitonin generelated peptide immunocytochemistry. J Endodont 14:577-587.

Kilbourn RG, Belloni P (1990). Endothelial cell production of nitrogen oxides in response to interferon in combination with tumor necrosis factor, interleukin-1, or endotoxin. J Natl Canc Inst 82:772-776.

Kilbourn RG, Jubran A, Gross SS, Griffith OW, Levi R, Adams J, et al. (1990). Reversal of endotoxin-mediated shock by $\mathrm{NG}^{\mathrm{G}}$ methyl-L-arginine, an inhibitor of nitric oxide synthase. Biochem Biophys Res Commun 172:1132-1138.

Kummer W, Fischer A, Mundel P, Mayer B, Hoba B, Philippin B, et al. (1992). Nitric oxide synthase in VIP-containing vasodilator nerve fibres in the guinea-pig. Neuroreport 3:653-655.

Lamas S, Marsden PA, Li G-K, Tempst P, Michel T (1992). Endothelial nitric oxide synthase: molecular cloning and characterization of a distinct constitutive enzyme form. Proc Natl Acad Sci USA 89:6348-6352.

Lohinai Z, Balla I, Marczis J, Vass Z, Kovach AG (1995). Evidence for the role of nitric oxide in the circulation of the dental pulp. J Dent Res 74:1501-1506.

Lohinai Z, Székely AD, Benedek P, Csillag A (1997). Nitric oxide synthase containing nerves in the cat and dog dental pulp and gingiva. Neurosci Lett 227:91-94.

MacNaul KL, Hutchinson NI (1993). Differential expression of iNOS and cNOS in human vascular smooth muscle cells and endothelial cells under normal and inflammatory conditions. Biochem Biophys Res Commun 196:1330-1334.

Madison S, Whitsel EA, Suarez-Roca H, Maixner W (1992). Sensitizing effects of leukotriene B4 on intradental primary afferents. Pain 49:99-104.

Marletta MA (1989). Nitric oxide: biosynthesis and biological significance. Trends Biochem Sci 14:488-492.

McCall TB, Palmer RM, Moncada S (1991). Induction of nitric oxide synthase in rat peritoneal neutrophils and its inhibition by dexamethasone. Eur J Immunol 21:2523-2527.

Moncada S, Palmer RMJ, Higgs EA (1991). Nitric oxide: physiology, pathology, and pharmacology. Pharmacol Rev 43:109142.

Mulligan MS, Hevel JM, Marletta MA, Ward PA (1991). Tissue injury caused by deposition of immune complexes is L-arginine dependent. Proc Natl Acad Sci USA 88:6338-6342.

Närhi MVO, Hirvonen T (1983). Functional changes in cat pulp nerve activity after thermal and mechanical injury to the pulp. Proc Finn Dent Soc 79:162-167.

Nathan CB, Hibbs JB Jr (1991). The role of nitric oxide synthesis in macrophage antimicrobial activity. Curr Opin Immunol 3:65-70.

Nussler AK, Billiar TR (1993). Inflammation, immunoregulation, and inducible nitric oxide synthase. J Leukocyte Biol 54:171-178.

Okiji T, Morita I, Sunada I, Murota S (1989). Involvement of arachidonic acid metabolites in increases in vascular permeability in experimental dental pulpal inflammation in the rat. Arch Oral Biol 34:523-528.

Olgart L, Edwall L, Gazelius B (1991). Involvement of afferent nerves in pulpal blood-flow reactions in response to clinical and experimental procedures in the cat. Arch Oral Biol 36:575-581.

Oswald RJ, Byers MR (1993). The injury response of pulpal NPYIR sympathetic fibers differs from that of sensory afferent fibers. Neurosci Lett 164:190-194.

Panopoulos P, Mejare B, Edwall L (1983). Effects of ammonia and organic acids on the intradental sensory nerve activity. Acta Odontol Scand 41:209-215.

Parks DA, Bulkley GB, Granger DN, Hamilton SR, McCord JM 
(1982). Ischemic injury in the cat small intestine: role of superoxide radicals. Gastroenterol 82:9-15.

Picton W, Clark C (1978). The measurement of histochemicallystained NADP dependent iscitrate dehydrogenase in the subcutaneous glands of hairless hamsters. Histochem J 10:191-199.

Poeggel G, Muller M, Seidel I, Rechardt L, Bernstein HG (1992). Histochemistry of guanylate cyclase, phosphodiesterase, and NADPH-diaphorase (nitric oxide synthase) in rat brain vasculature. J Cardiovasc Pharmacol 20(12):S76-S79.

Pohto P, Antila R (1970). Assay of histamine in dental pulps. Acta Odontol Scand 28:691-699.

Pulver WH, Taubman MA, Smith DJ (1977). Immune components in normal and inflamed human dental pulp. Arch Oral Biol 22:103-111.

Rees DD, Palmer RM, Schulz R, Hodson HF, Moncada S (1990). Characterization of three inhibitors of endothelial nitric oxide synthase in vitro and in vivo. Br J Pharmacol 101:746-752.

Sessa WC, Harrison JK, Barber CM, Zeng D, Durieux ME, D'Angelo DD, et al. (1992). Molecular cloning and expression of a cDNA encoding endothelial cell nitric oxide synthase. $J$ Biol Chem 267:15274-15276.

Silverman JD, Kruger L (1987). An interpretation of dental innervation based upon the pattern of calcitonin gene-related peptide (CGRP) immuno-reactive thin sensory axons. Somatosens Res 5:157-175.

Stuehr DJ, Cho HJ, Kwon NS, Weise MF, Nathan CF (1991). Purification and characterization of the cytokine-induced macrophage nitric oxide synthase: an FAD- and FMN-containing flavoprotein. Proc Natl Acad Sci USA 88:7773-77777.

Takahashi K (1990). Changes in pulpal vasculature during inflammation. J Endodont 16:92-97.

Uddman R, Björlin G, Möller B, Sundler F (1980). Occurrence of VIP nerves in mammalian dental pulps. Acta Odontol Scand 38:325-328.

Wakisaka S, Ichikawa H, Nishimoto T, Matsuo S, Yamamoto K, Nakata T, et al. (1984). Substance P-like immunoreactivity in the pulp-dentine zone of human molar teeth demonstrated by indirect immunofluorescence. Arch Oral Biol 29:73-75.

Ward SM, Xue C, Shuttleworth CW, Bredt DS, Snyder SH, Sanders KM (1992). NADPH diaphorase and nitric oxide synthase colocalization in enteric neurons of canina proximal colon. Am J Physiol 263:G277-G284.

Werner-Felmayer G, Werner ER, Fuchs D, Hausen A, Reibnegger G, Wachter H (1990). Tetrahydrobiopterin-dependent formation of nitrite and nitrate in murine fibroblasts. I Exp Med 172:1599-1607.

Wilcox JN, Subramanian RR, Sundell CL, Tracey WR, Pollock JS, Harrison DG, et al. (1997). Expression of multiple isoforms of nitric oxide synthase in normal and atherosclerotic vessels. Arteriosd Thromb Vasc Biol 17:2479-2488.

Willis RA, Nussler AK, Fries KM, Geller DA, Phipps RP (1994). Induction of nitric oxide synthase in subsets of murine pulmonary fibroblasts: effect on interleukin-6 production. Clin Immunol Immunopathol 71:231-239. 